\title{
Positive School Climate (A Theoretical Empirical Conspectus)
}

\author{
Jana Hanuliaková - Silvia Barnová ${ }^{*}$
}

\begin{abstract}
A school climate is the product of a specific social group. It influences the work of both teachers and students; it is a reflection of the objective reality in schools. It is experienced, evaluated and perceived by the actors of school life subjectively. In agreement with the current approaches to education (neuropedagogy, neuroscience), the importance of a positive school climate is accentuated. It is a part of school environment in the emotional, social and physical contexts. We put an accent on the interconnection and mutual determination of the climate and some selected determinants - inappropriate behaviour, interaction and safe educational environment. Nowadays, the notion of the school climate is joined with the adjective "optimal". Based on the undertaken research, we make a conspectus of empirical findings which are related to school environment and school climate.
\end{abstract}

Key words: school climate, safe environment, aggression, interaction.

\section{Introduction}

In the last year, the modern approach to education accentuates the need for the creation of optimal educational conditions. The conditions of education are created by a wide spectrum of external and internal factors. The educational conditions, inter alia, include the educational environment of the school and classrooms, school and classroom climate and the current atmosphere. From the point of view of duration, the school climate can be defined as a long-term phenomenon. It influences interaction in schools, manifestation of students' behaviour, motivation, achieved results etc. The process of school climate creation in the current context must focus on the provision of a safe environment and the optimisation of school climate. The character of a safe educational environment consists of emotional, social and physical components, norms and rules, their application and obeying, and the quality of mutual interaction. At present, recognising the importance of a secure educational environment plays a

\footnotetext{
* Jana Hanuliaková, Dubnica Institute of Technology in Dubnica nad Váhom, Dubnica nad Váhom, Slovakia; hanuliakova@dti.sk

Silvia Barnová, Dubnica Institute of Technology in Dubnica nad Váhom, Dubnica nad Váhom, Slovakia; barnova@dti.sk
} 


\section{Acta Technologica Dubnicae \\ volume 5, 2015, issue 1}

big role in relation to the occurrence of students' inappropriate behaviour (bullying, aggression), which has a significant impact on the quality of school life.

Based on studied research and professional literature we can assume that the definitions of the notion of school climate vary with different authors (Sackney, 1988; Anderson, 1982; Freiberg and Stein, 1999). It can be explained by the fact that the term climate can mean anything in a school. The common feature of the definitions lies in describing it as something interpersonal, some kind of a product, the result of personal relationships forming the phenomenon of a particular school. Čapek (2010) characterises a school climate as the result of participants' self-evaluation and evaluation of education at a particular school taking into account all the aspects of education. Their mutual communication, social relationships, perception of the environment, experiences, emotions and other social and psychical processes belong here. Several authors, e.g. Dotka (2009), Grecmanová (2008), Ježek (2005), Bessoth (2003), Littg (1986), Fraser (1984), Gregory and Smith (1982), Lewin (1982), Moss (1978), Fox (1974) et al., have brought a theoretical analysis of the notion of school climate.

\section{Discussion}

School climate and school environment have been the subject of many research studies oriented on their individual determinants. Neuroscience and neurodidactical approaches to education appeal on the necessity of creation of such a climate and atmosphere that can be characterised by safety, emotional well-being, social acceptance, and high quality interaction.

According to Mareš (2004, p. 39), we can consider three main levels of studying the school climate: the micro, mezo and macro level. If we are interested only in one school and its climate, we are on the micro level of studying the school climate. Going under this level (and to deal only with it) would mean, that we are not dealing with the climate of the whole school but with the climate of one of its parts, e.g. only the teaching staff or only one class. It is useful as the starting point on the way to studying the climate of the whole school. If we want to learn something more general about the climate of schools of the same type based on a representative sample (research), then it is (in our country) the macro level of the climate being studied. The mezo level of studying the school climate is not strictly defined. It can be characterised as territorial (e.g. region), administrative (e.g. a school district) or by the type of school (e.g. secondary vocational schools). It can be defined by other criteria as well, i.e. the educational project, the founder, the type of community in which it functions, the composition of students attending the school etc. Thapa and Cohen (2013) bring complex empirical findings regarding school climate. They summarised research dealing with school climate and educational environment with a special focus on individual determinants (perception of safety, following norms and 


\section{Acta Technologica Dubnicae \\ volume 5, 2015, issue 1}

rules, the quality of interaction, inappropriate behaviour - aggression). The above mentioned components form the complex of school climate quality which subsequently influences them. A positive school climate results in better outcomes of both the teachers' and students' work. Students associate positive school climate with a higher motivation to study, experiencing success; personal development; discovery learning which bring them pleasure; increasing prosocial attitudes and behaviour. For teachers, positive perception of school climate is associated with experiencing emotional harmony and feeling of companionship with other teachers; a higher degree of job satisfaction, productivity; with freedom and independence at work; consistency in the process of realisation of new initiatives; lower appearance of burn-out effect (Grecmanová, 2008, p. 86). Similar arguments are used by Cohen and Greier (2010). They indicate that a safe and careful participatory school environment provides an optimal basis for teaching. The current situation in the educational reality requires focusing on experiencing safety in schools and classrooms. The mentioned notion relates to safety in the field of emotions, social and physical relations, and physical health. Experiencing social, emotional and physical safety belongs to basic human needs. The feeling of safety and its components in school are evaluated in research especially based on students' responses as they are the active participants of the creation process. Feeling safe intensively promotes student's learning and healthy development (Devine and Cohen, 2007, cited in Thapa and Cohen, 2013). The authors state that many students do not feel physically and psychically safe because of the failure of interpersonal relationships that form the character of a school climate. A negative perception of safety in schools was proven in the context of school size - a decreased feeling of safety was declared by students of bigger schools (Lleras, 2008). Another important factor decreasing the feeling of safety in the conditions of a particular school is represented by presence of students' aggressive behaviour and consequent bullying which have an increasing tendency. The appearance of this negative phenomenon causes a decreased interest of students in school life participation. On the sample of 2000 students aged 12-16, Rivers, Noret and Ashurt (2009) found out that the witnesses of bullying experience depression, anxiety and hostility.

The diversity of student population (race, gender, sexual identity, disabilities, socio-economic differences, cultural differences etc.) represents the reason for bullying in many cases. In their study, Thapa and Cohen (2013) bring their research results confirming the role of schools' psycho-social climate in the context of aggression and bullying. Decreasing aggression and violence in schools is related to a positive school climate (Brookmeyer, Fanti and Henrich, 2006; Goldstein, Young and Boyd, 2008; Gregory et al., 2010; Karcher, 2002). A lower appearance of bullying related to a positive school climate has been proven by research (Birkett et al., 2009; Kosciw and Elizabeth, 2006, 


\section{Acta Technologica Dubnicae \\ volume 5, 2015, issue 1}

Meraviglia, Becker, Rosenbluth, Sanchez and Robertson, 2003; Meyer-Adams and Conner, 2008; Yoneyama and Rigby, 2006).

In the last years, we have observed an increased occurrence of bullying transformed into the virtual level. Nowadays, cyberbullying is a serious issue that decreases the emotional and social well-being of students. According to Campbell (2005), school bullying and harassment have moved to a virtual school represented by social media being used by groups or individuals with the purpose to harass their peers. In Slovakia, Hollá (2013) has undertaken a research in the given field. As bullying in schools is present in its emotional, social and physical forms, it is necessary to study, evaluate, eliminate it and prevent the occurrence of aggressive behaviour in the future.

The connection and the mutual conditionality of positive school climate and students' risk behaviour are documented in research by Klein, Cornell and Konold (2012, cited in Thapa and Cohen (2013). The elimination of aggressive behaviour in schools and of the appearance of bullying can be realised only by instilling discipline. A strict application of school discipline is closely related to safety in schools. School discipline requires following rules. The rules and the obedience to those rules form a part of the educational process. The character of the environment in which the educational process takes place requires a necessary definition and the consequent interiorisation of rules on the side of students. Rules and norms in schools ensure optimal conditions for education. Research emphasise the role of school rules and the perception of justice in the context of students' behaviour. Some research evidence exists regarding the fact that in schools, where the rules are followed, the application of discipline is more effective. Following the school rules and their regular and careful appreciation are significant factors of safety in schools. A research on following and appreciation of norms, rules and discipline in school conditions has been done by Gregory et al. (2010), Gottfredson, Payne and Gottfredson (2005).

Practical recommendations for teachers on how to create an emotionally safe school and classroom are introduced by Perry (2000). Ensuring safety in the classroom requires: continuous repetition of rules; introduction and application of changes is easier when students feel comfortable; planning the interaction with students, creation of such a place that gives students an opportunity for satisfaction; providing (during the school day) calm situations in which the student processes new experiences which lead to a more effective consolidation of new experiences and to better learning; providing opportunities to experience success; emphasizing the importance of students" nutrition; working with unpleasant experiences which can be stressful for students. The author accentuates that the first experiences with school can help foster students' interest in school and love to learning. Teachers can create a climate of emotional and social safety that supports optimal education in the classroom.

The quality of the school climate is influenced by interaction. In the context of the quality of Eliot's social relations, Cornell, Gregory and Fan (2010) outline 


\section{Acta Technologica Dubnicae \\ volume 5, 2015, issue 1}

how to work with students when reporting bullying. Teachers play an important

role in this process. Reporting and drawing attention to bullying is significantly influenced by help on the side of adults (Klein et al., 2012). The research results by Saarento et al., (2013), Swearer, Espelage, Vaillancourt and Hymel, (2010, cited in Thapa and Cohen, 2013) document the probability of increasing bullying in cases when teachers are unconcerned about the appearance of bullying or their reactions to bullying vary.

\section{Conclusions}

According to V. Zakrzewski (2013), in 2007, specific criteria were formulated defining positive school climate as "norms, values and expectations that promote social, emotional and physical security; respect for other people (teachers, students, parents, non-pedagogical staff), which collaborate on the shared vision of a school". This author mentions three steps of positive school climate creation which can be applied in practice. The following steps are oriented on creation of trust between participants (teachers, students, school management, nonpedagogical employees and parents).

a) Evaluation of the current climate - it requires knowledge on how the current school climate is perceived and what we want to achieve by creation of a positive climate

b) To create a common vision - to start from personal visions - bring collective suggestions which can increase the probability of the realisation of research. In the given context vision is understood as the picture of the future. Creating shared images regarding the future character of the climate requires a safe environment in which the members can share their ideas and suggestions.

c) To cooperate in the realisation of the common vision - making fun - creation of a positive school climate is a never-ending process. Positive emotions are important.

The cited author states that a positive school climate can bring back pleasure and fun into the educational process. Who would not like to be a part of a school like that?

The above mentioned research studies highlight the importance of paying attention to school climate and safe environment as they have a strong impact in the educational practice.

The paper was written as a part of the research task KEGA 036UKF-4/2014 „Influencing Aggressive Behaviour of Students by Means of Creating a Positive School and Class climate. " 


\section{References}

COHEN, J., and THAPA, A. A review of School Climate. Review of Educational Research. [online]. 83, September 2013, pp. 357-385. [viewed 3 February 2015]. Available from:

$<$ http://rer.sagepub.com/content/early/2013/04/18/0034654313483907.full.pdf+h tml?ijkey=lPFDtiKJJYWkE\&keytype=ref\&siteid=sprer $>$

COHEN, J., and GEIER, V. K. School Climate Research Summary [online]. New York: 2010 [viewed 29 January 2015]. Available from: $<$ www.schoolclimate.org/climate/research.php>

COHEN, J. Measuring and improving school climate: Creating a climate for learning. Independent School (A publication of the National Association of Independent Schools). 67, 1, 2007, pp. 18-26. [viewed 4 April 2015]. Available from: $<$ http://www.nais.org/publications/ismagazinearticle.cfm?Itemnumber= 150284\&sn.ItemNumber $=1$ 45956>

ČAPEK, R. Tř́íni klima a školni klima. Praha: Grada, 2010.

GAGE, N. A. et al. School Climate and Bullying Victimization: A Latent Class Growth Model Analysis. American Psychological Association. School Psychology Quarterly. [online]. 29, 2014, 3, pp. 256-271. [viewed 4 April 2015]. Available from: <http://www.apa.org/pubs/journals/features/spq-0000064.pdf > GRECMANOVÁ, H. Klima školy. Olomouc: Hamex, 2008.

HOLLÁ, K. Kyberšikana. Bratislava: IRIS, 2013.

MAREŠ, J. Morální, etické a sociální aspekty školního klimatu. JEZEK, S. (ed.) Psychosociálni klima školy II. Brno: MSD, 2014, pp. 86-93.

PERRY, B. D. Creativing an Emotionally Safe Classroom. Early Childhood Today. [online]. 15, August/September 2000, 1, p. 35. [viewed 3 february 2015]. Available from: $<$ http://teacher.scholastic.com/professional/bruceperry/safety_ wonder.htm\#author>

RIVERS, I., POTEAT, V. P., NORET, N., and ASHURST, N. Observing bullying at school: The mental health implications of witness status. School Psychology Quarterly. [online]. 24, 2009, 4, pp. 211-223. doi:10.1037/a0018164. [viewed 1 February 2015]. Available from: $<$ http://www.apa.org/pubs/journals/releases/spq-24-4-211.pdf>

ZAKRZEWSKI, V. How To Create Positive School Climate. Greater Good the Science of a meaningful Life. [online]. August 2013. [viewed 8 February 2015]. Available from:

$<$ http://greatergood.berkeley.edu/article/item/how_to_create_a_positive_school_ climate>

http://www.wellbeingatschool.org.nz/sites/default/files/W@ @S-Building-a-safeand-caring-climate-research-brief.pdf 